\title{
Pathological features of COVID-19 infection from biopsy and autopsy series
}

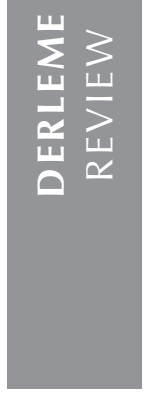

Sidar ÇOPUR ${ }^{\mathbf{1}}(\mathrm{ID})$

Asiye KANBAY ${ }^{2}(I D)$

$\operatorname{BarıŞ~AFŞAR~}^{3}(I D)$

Rengin ELSÜRER

$\operatorname{AFŞAR}^{3}$ (ID)

Mehmet KANBAY ${ }^{1}($ ID)
${ }^{1}$ Department of Internal Medicine, Faculty of Medicine, Koc University, Istanbul, Turkey

${ }^{1}$ Koç Üniversitesi Tıp Fakültesi, iç Hastalıkları Anabilim Dalı, istanbul, Türkiye

${ }^{2}$ Department of Chest Diseases, Faculty of Medicine, Istanbul Medeniyet University, Istanbul, Turkey

2 Istanbul Medeniyet Üniversitesi Tıp Fakültesi, Göğüs Hastalıkları Anabilim Dalı, Istanbul, Türkiye

${ }^{3}$ Department of Internal Medicine, Faculty of Medicine, Suleyman Demirel University, Isparta, Turkey

3 Süleyman Demirel Üniversitesi Tıp Fakültesi, iç Hastalıkları Anabilim Dalı, Isparta, Türkiye
Cite this article as: Copur S, Kanbay A, Afșar B, Elsürer Afşar R, Kanbay M. Pathological features of COVID-19 infection from biopsy and autopsy series. Tuberk Toraks 2020;68(2):160-167.

\section{Yazışma Adresi (Address for Correspondence)}

\section{Dr. Asiye KANBAY}

İstanbul Medeniyet Üniversitesi Tıp Fakültesi, Göğüs Hastalıkları Anabilim Dalı,

ISTANBUL - TÜRKIYE

e-mail: kanbaydr@yahoo.com

(C) Copyright 2020 by Tuberculosis and Thorax. Available on-line at www.tuberktoraks.org.com

\section{ABSTRACT}

Pathological features of COVID-19 infection from biopsy and autopsy series

Novel coronavirus disease 2019 (COVID-19) which is caused by severe acute respiratory syndrome corona virus 2 (SARS-CoV-2) was first identified in December 2019 in Chinese town Wuhan and considered as a pandemic by World Health Organization. The disease has variety of symptoms including fever, shortness of breath, cough, fatigue, loss of smell and taste and diarrhea. While the majority of cases have mild symptoms, some progress to viral pneumonia, multi-organ failure, or cytokine storm and mortality is mostly caused by hypoxemic respiratory failure. Until now, more than 3.5 million people worldwide were infected and more than 240.000 mortality has been occurred. Thus, there is now evidence the disease may affect variety of organs according to accumulating biopsy and autopsy studies. Such pathological studies have potential role on the understanding of clinical outcomes and in the development of novel targeted therapeutic approaches. Given these aforementioned data, in the current manuscript we have summarized the pathological features of COVID-19 derived from biopsy and autopsy series.

Key words: COVID-19; lung injury; kidney injury; heart injury; biopsy; autopsy

ÖZ

COVID-19 infeksiyonunun otopsi ve biyopsi raporlarına göre patolojik özellikleri

Yeni koronavirüs 2019 hastalığı (COVID-19) akut respiratuvar sendromu korona virüs 2 (SARS-COV-2) ilk olarak Çin'in Wuhan şehrinde aralık 2019 tarihinde saptanmış olup, dünya sağlık örgütü tarafından pandemi olarak kabul edilmiştir. COVID-19 infeksiyonu ateş, nefes darlığı, öksürük, halsizlik, ishal, 
koku ve tat alma bozukluğu gibi şikayetlere neden olabilmektedir. Hastalık yüksek oranda asemptomatik geçirilse bile bazı hastalarda viral pnömoni, solunum yetmezliği, çoklu organ yetmezliği ve sitokin fırtınası gelişebilmekte ve ölüme neden olabilmektedir. Şimdiye kadar 3.5 milyonun üzerinde insan enfekte olmuş olup, 240.000 üzerinde insan ölmüştür. Biyopsi ve otopsi raporlarında akciğer dışı birçok organında tutulduğu gösterilmiştir. Bu bilgilerin yeni tedavi modalitelerinin gelişmesine yardımcı olabileceği ümit edilmektedir. Bu derlemede COVID-19 infeksiyonu olan hastalarda yapılmış biyopsi ve otopsi raporlarında covid enfeksiyonuna bağlı organ tutulumları ve tipleri detaylıca tartışılmıştır.

Anahtar kelimeler: COVID-19; akciğer hasarı; kalp hasarı; böbrek hasarı; otopsi; biyopsi

\section{INTRODUCTION}

As third recent outbreak of Coronaviruses family following severe acute respiratory syndrome (SARS) and Middle East respiratory syndrome (MERS) viruses, coronavirus disease 2019 (COVID-19) pandemic has originated in a Chinese town Wuhan in December 2019 and infected more than 3.5 million people worldwide with more than 240.000 mortality so far (1). Most common clinical presentation features include fever $(88.5 \%)$, cough $(68.6 \%)$, fatigue (35.8) and dyspnea $(21.9 \%)$ as reported by a meta-analysis study involving 1995 cases while fatality rate is around 5\% with predominant cause of mortality being acute respiratory failure (2). 20.3\% intensive care unit admission requirement has been demonstrated in another meta-analysis involving 656 patients while $88 \%$ of ICU-admitted patients required respiratory support $(3,4)$. Primary mode of transmission is through respiratory droplets while fecal-oral transmission has been implicated in few studies (5). Entrance of viral particles into pneumocytes and bronchial epithelial cells, primary sites of involvement, is mediated via interaction between angiotensin converting enzyme (ACE)-2 receptors and a protein domain with SARS-CoV cellular binding spike (6). Older age, presence of comorbid diseases and secondary infections, elevated inflammatory markers, high d-dimer and cardiac troponin levels, higher Sequential Organ Failure Assessment (SOFA) score and low T-cell count are shown to be statistically significant predictive factors for mortality $(7,8)$. Currently there is no vaccine or medication approved by Food and Drug Administration (FDA) except emergency use approval for remdesivir, a RNA-dependent RNA polymerase inhibitor, despite few studies demonstrating inefficiency in COVID-19 treatment $(9,10)$. In this study, we aim to evaluate the current knowledge about the pathological features of COVID19 infection at organ systems on biopsy and autopsy samples and possible discuss the rationale behind new therapeutic trials.

\section{PULMONARY SYSTEM}

Acute respiratory failure, followed by fulminant myocarditis, is the most common cause of mortality in COVID-19 infected patients. High rate of respiratory and cardiovascular (CVS) involvement is believed to be linked to higher expression of ACE-2 receptors at that tissues (11). Respiratory symptoms are more severe in patients with comorbid CVS disorders and diabetes mellitus, presumably due to higher expression of ACE-2 receptors, which leads to hypothesis that use of ACE inhibitors (ACEi) and/or angiotensin-receptor blockers (ARB) may lead to higher susceptibility towards COVID-19 infection and poor clinical outcome (12-14). However, current evidence does not support abandonment of ACEi/ARB therapy in hypertension. In addition to being most commonly involved site in COVID-19 infection with symptoms including fever, dyspnea and cough, various laboratory, imaging and pathological findings have been demonstrated. Most common findings observed on chest X-ray studies are bilateral infiltration and ground-glass opacities while most common laboratory findings are elevated C-reactive protein (CRP), erythrocyte sedimentation rate (ESR), lymphopenia, hypoalbuminemia and high lactate dehydrogenase (LDH) levels (15). Pathological findings obtained from infected patients are consistent with diffuse alveolar damage (DAD) and early-phases of acute respiratory distress syndrome (ARDS). Viral particles have been obtained from respiratory tract epithelium and type II pneumocytes while contradictory findings have been reported regarding the presence of viral inclusions at respiratory cells. Main pathological findings include necrosis at respiratory epithelium, focal interstitial thickening and fibrosis, congested and edematous blood vessels, high amount of protein-rich inflammatory infiltration containing predominantly monocytes, macrophages and lymphocytes. Findings about hyaline membrane formation and intra-alveolar hemorrhages are inconclusive. General pathological features obtained on biopsy and autopsy samples are 
summarized at Table 1. Similarities of COVID-19 infection and ARDS raise the possibility of immunotherapy use in the treatment. Tocilizumab, an IL-6 receptor antagonist approved in the treatment of cytokine release syndrome by FDA, is one such option for which clinical trials are ongoing since elevated levels of interleukin (IL)-2, IL-6, IL-10, tumor necrosis factor (TNF) and interferon-gamma (IFN- $\gamma)$ are reported at infected individuals $(16,17)$. Melatonin, an anti-inflammatory and anti-oxidant molecule shown to reduce acute respiratory stress caused by pathogens, is hypothesized to have beneficial effects in the control of DAD and ARDS that developed in the course of COVID-19 infection (18). Similarly,

\section{Table 1. Pathological findings of COVID-19 infection on biopsy and autopsy series in accordance with organ systems.}

\begin{tabular}{|c|c|}
\hline Organ systems & Pathological findings on biopsy and autopsy \\
\hline Pulmonary system (58-69) & $\begin{array}{l}\text { Edema with protein-rich exudate and patchy inflammatory infiltration predominantly including } \\
\text { macrophages and monocytes } \\
\text { Focal reactive hyperplasia of type II pneumocytes and multinucleated giant cells with nuclear } \\
\text { atypia } \\
\text { Inconsistent findings regarding hyaline membrane formation, intra-alveolar hemorrhages and } \\
\text { intracytoplasmic viral inclusion bodies } \\
\text { Congested, edematous and widened vessels around alveoli } \\
\text { Necrosis of bronchiolar wall and epithelial cells (Consistent with necrotizing bronchiolitis) } \\
\text { Focal interstitial thickening and fibrosis } \\
\text { Mild to none effusion or adhesion } \\
\text { Consistent with diffuse alveolar damage and early phase of ARDS }\end{array}$ \\
\hline Heart $(60-62,66)$ & $\begin{array}{l}\text { Mild to none interstitial mononuclear inflammatory infiltrates } \\
\text { Dilatation especially at right ventricle } \\
\text { Focal myocardial necrosis }\end{array}$ \\
\hline Kidney $(38,39,70,71)$ & $\begin{array}{l}\text { Diffuse and prominent proximal tubular injury including brush border loss, vacuolar degeneration } \\
\text { with varying size and focal necrosis } \\
\text { Effacement of foot processes at podocytes } \\
\text { Presence of hyaline casts } \\
\text { Obstructed capillaries with RBC aggregates without platelets or fibrin plugs } \\
\text { Upregulation of ACE2 receptors on immunostaining } \\
\text { Crescentic proliferative glomerulonephritis } \\
\text { Collapsing glomerulopathy } \\
\text { Mild to none inflammatory or lymphocytic infiltration } \\
\text { Consistent with AKI and ATN }\end{array}$ \\
\hline Liver $(60-62,69)$ & $\begin{array}{l}\text { Moderate microvesicular steatosis, centrilobular steatosis, mild sinusoidal dilatation } \\
\text { Mild to none inflammatory or lymphocytic infiltration }\end{array}$ \\
\hline Spleen $(59,61,72)$ & $\begin{array}{l}\text { Decline in lymphocyte follicles and count including B and T-cells } \\
\text { No difference in NK cell count } \\
\text { Necrosis of parenchymal cells } \\
\text { Hyaline thrombus formation at small vessels } \\
\text { Atrophy at pulps }\end{array}$ \\
\hline Skin $(53,59,73-76)$ & $\begin{array}{l}\text { Edema with diffuse lymphocytic infiltration predominantly at perivascular area and dermis } \\
\text { Focal areas of spongiosis, necrosis and basal cell vacuolization } \\
\text { Thrombogenic vasculopathy }\end{array}$ \\
\hline CNS (61) & No gross abnormality \\
\hline GIS (61) & No gross abnormality except increased fatty infiltration \\
\hline Genital system (61) & No gross abnormality \\
\hline Endocrine system (61) & No gross abnormality \\
\hline Musculoskeletal system (61) & No gross abnormality \\
\hline
\end{tabular}

Abbreviations: ACE: Angiotensin converting enzyme, RBC: Red blood cell, NK: Natural killer, ARDS: Acute respiratory distress syndrome, AKI: Acute kidney injury, ATN: Acute tubular necrosis. 
Chimeric Antigen Receptor T Cell Therapy (CAR-T), plasma therapy, immunoglobulin therapy, thymosin, corticosteroids, anakinra (IL-1 receptor antagonist), immunoglobulin FC domains, siltuximab (IL-6 antagonist) and many others have been implicated (19-21). Furthermore, another hypothesis based on similarity between COVID-19 infection and high altitude pulmonary edema in terms of clinical, laboratory and pathological features suggest potential use of acetazolamide, nifedipine and phosphodiesterase inhibitors such as sildenafil and tadalafil (22).

\section{CARDIOVASCULAR SYSTEM and KIDNEY}

Common cardiovascular comorbidities of COVID-19 infection include acute myocarditis, myocardial injury, acute myocardial infarction (AMI), acute heart failure and cardiomyopathy, thromboembolism and arrhythmia (23-25). 7-17\% of hospitalized patients and $22-31 \%$ of ICU-admitted patients show elevated high sensitive troponin levels with mononuclear cell infiltration at myocardium on pathological samples which is consistent with acute myocarditis $(26,27)$. Additionally, elevated pro-inflammatory cytokines and severe systemic inflammation markers have been associated with AMI $(28,29)$. Although direct link between AMI and COVID-19 infection has not been established so far, strong hypothesis exists regarding the increased risk associated with viral infections including Influenza in earlier studies (30). Most commonly reported arrhythmia is sinus tachycardia and most likely have multifactorial etiology including pro-inflammatory status, hypoxia and fever (31). Another important CVS aspect of COVID-19 infection demonstrated on few case reports which may be caused by pro-inflammatory status, prolonged immobilization, dysfunction at coagulation cascade and multi-organ failure $(32,33)$. In a retrospective study conducted with 191 patients d-dimer levels above 1 $\mu \mathrm{g} / \mathrm{mL}$ has shown to be associated with increased mortality (34). Supporting evidence is demonstrated by a study conducted with 499 patients from which 99 patient received low dose heparin for at least 7 days that shows beneficial effects of low dose heparin administration on survival in patients with d-dimer greater than six times the upper limit of normal (35). Autopsy and biopsy studies investigating cardiac findings are limited in number while most common findings are mild including ventricular dilatation, focal myocardial necrosis and inflammatory infiltration (Table 1).
Elevated baseline serum creatinine, blood urea nitrogen, $\mathrm{AKI}$, proteinuria and hematuria are identified as independent risk factors for in-hospital deaths according to a prospective cohort study including 701 patients (36). High rates of kidney involvement has been implicated in the course of COVID-19 infection. $65.8 \%$ proteinuria and $41.7 \%$ hematuria rates have been demonstrated in a study conducted with 333 infected patients while such high rates are seen in the course of many critical illness (37). However, rates of acute kidney injury (AKI) $(7.5 \%)$ is considerably high compared to other illnesses suggesting direct viral involvement. Viral particles have been detected at tubular epithelium. Effacement of podocytes foot processes, prominent proximal tubular injury including loss of brush borders, necrosis and vacuolar degeneration, upregulation of ACE-2 receptors and obstructed capillaries with RBC aggregates without platelets or fibrin plugs are key pathological findings (Table 1) which is consistent with an AKI developing as a result of acute tubular necrosis (ATN). It was also shown that covid-19 may cause collapsing glomerulopathy or crescentic proliferative glomerulonephritis resulting in acute kidney injury $(38,39)$.

\section{LIVER, SPLEEN and GASTROINTESTINAL SYSTEM}

Primary sites of involvement at COVID-19 infection in gastrointestinal system are liver, gastrointestinal tract and spleen. Most commonly encountered gastrointestinal symptoms in the course of COVID-19 infection are anorexia (39.9-50.2\%), diarrhea (2-49.5\%), vomiting 3.6-66.7\%), nausea (1-29.4\%), abdominal pain $(2.2-6.0 \%)$ and gastrointestinal bleeding (4-13.7\%) (40). $39.4 \%$ of patients have elevated aspartate aminotransferase (AST) and $28.1 \%$ have elevated alanine aminotransferase (ALT) level in a study from China conducted with 1099 patients (Median age $=47,27 \%$ with at least one comorbid disorder) while most elevations are mild and not associated with liver failure or cholestasis (41). Similar abnormal liver function tests have been reported in multiple studies (42-44). Pathological features of COVID-19 infection at liver include moderate microvesicular steatosis, centrilobular steatosis and mild sinusoidal dilatation while inflammatory alterations and infiltration are mild. Possible mechanism of liver injury includes direct viral replication at hepatocytes which have considerable ACE-2 receptor expression, hypoxic injury in response to respiratory failure, immune-mediated damage, drug-induced 
liver injury in response to multiple anti-viral and anti-inflammatory therapy and reactivation of pre-existent disease such as hepatitis B reactivation in response to tocilizumab therapy (45-47). Glycyrrhizic acid, an anti-inflammatory drug used in liver diseases for many years, have been proposed as a potential medication to manage liver dysfunction along with ACE-2 signaling pathway modulators including ACE-2/Ang-II/Mas signaling pathway activators and ACE-2/Ang-II/AT1R pathway inhibitors $(48,49)$.

Another important site of COVID-19 infection is spleen, important regulator and center of immune system, in which viral particles are demonstrated. Pathological findings at spleen include decline in lymphocytes including cytotoxic T-cells, helper T-cells and B-cells, atrophy at white and red pulps, parenchymal necrosis and thrombus formation at smallsized vessels. Only major abnormality reported at gastrointestinal tract is increased adipose tissue infiltration while viral particles are demonstrated at intestines. General pathological features obtained on biopsy and autopsy samples are summarized at Table 1.

\section{OTHER ORGAN SYSTEMS}

Skin manifestations of COVID-19 are poorly described while various inflammatory (ie. exanthema, chicken-pox like vesicular lesions, urticaria) and vascular lesions (ie. livedo, necrotic and non-necrotic purpura, chilblain, eruptive cherry angioma) have been reported in retrospective studies (50-54). Most common site of involvement is trunk. Analysis of clinical manifestation of 1099 patients revealed that only $0.2 \%$ incidence of skin rash while incidence rates are considerably higher in more recent studies $(55,56)$. Additionally, COVID-19 infection has been hypothesized as potential trigger for new onset or worsening of rheumatologic skin diseases similar to other members of Coronaviruses family but not yet proven (57). Drug-induced alterations, microvascular injury, immune system over-activation and secondary viral infections with mostly Herpesviruses family including Herpes simplex virus (HSV) and Varicella Zoster virus (VZV) have been proposed as potential etiological factor for skin manifestations while skin biopsy findings are correlated with viral infections (Table 1). Predominant features on skin biopsy samples are perivascular and dermal lymphocytic infiltration, microvascular thrombosis and vacuolar degeneration.
Until now no pathological abnormality on biopsy and autopsy samples have been recorded in musculoskeletal system, endocrinological system, genital system and central nervous system.

\section{CONCLUSIONS}

Although COVID-19 is a recent infection, the health, economic and social impact of the disease cannot be ignored due to its high infectious rate and relatively higher mortality. COVID-19 affected more than 185 countries which is the reason that the World Health Organization designate is as pandemic. New studies are coming up regarding the biopsy and autopsy findings of COVID-19 and it seems that various organs are affected (ie. lungs, heart, kidney, gastrointestinal system and skin). The most commonly affected organs are lungs and followed by heart and kidneys with various pathological findings. However, the data is only at infancy and it is probable that future studies will be able describe more about the pathological findings related with COVID-19 which is crucial for the development of targeted therapeutic options.

\section{ACKNOWLEDGEMENTS}

MK gratefully acknowledge use of the services and facilities of the Koç University Research Center for Translational Medicine (KUTTAM), funded by the Presidency of Turkey, Presidency of Strategy and Budget. The content is solely the responsibility of the authors and does not necessarily represent the official views of the Presidency of Strategy and Budget."

\section{REFERENCES}

1. Jin Y, Yang H, Ji W, Wu W, Chen S, Zhang W, et al. Virology, epidemiology, pathogenesis, and control of COVID-19. Viruses 2020;12(4).

2. Li LQ, Huang $T$, Wang $Y Q$, Wang $Z P$, Liang $Y$, Huang $T B$, et al. COVID-19 patients' clinical characteristics, discharge rate, and fatality rate of meta-analysis. J Med Virol 2020.

3. Rodriguez-Morales AJ, Cardona-Ospina JA, GutierrezOcampo E, Villamizar-Pena R, Holguin-Rivera Y, EscaleraAntezana JP, et al. Clinical, laboratory and imaging features of COVID-19: A systematic review and meta-analysis. Travel Medicine and Infectious Disease 2020;101623.

4. Grasselli G, Zangrillo A, Zanella A, Antonelli M, Cabrini L, Castelli $A$, et al. Baseline characteristics and outcomes of 1591 patients infected with SARS-CoV-2 admitted to ICUs of the Lombardy Region, Italy. JAMA 2020.

5. Gu J, Han B, Wang J. COVID-19: gastrointestinal manifestations and potential fecal-oral transmission. Gastroenterology 2020. 
6. Zhang $H$, Penninger $M M, L i Y$, Zhong $N$, Slutsky AS. Angiotensin-converting enzyme 2 (ACE2) as a SARSCoV-2 receptor: molecular mechanisms and potential therapeutic target. Intensive Care Medicine 2020;1-5.

7. Ruan Q, Yang K, Wang W, Jiang L, Song J. Clinical predictors of mortality due to COVID-19 based on an analysis of data of 150 patients from Wuhan, China. Intensive Care Medicine 2020;1-3.

8. Henry BM, de Oliveira MHS, Benoit S, Plebani M, Lippi G. Hematologic, biochemical and immune biomarker abnormalities associated with severe illness and mortality in coronavirus disease 2019 (COVID-19): a meta-analysis. Clinical Chemistry and Laboratory Medicine (CCLM) 2020;1 (ahead-of-print)

9. Wang $Y$, Zhang D, Du G, Du R, Zhao J, Jin $Y$, et al. Remdesivir in adults with severe COVID-19: a randomised, double-blind, placebo-controlled, multicentre trial. The Lancet 2020.

10. Gordon CJ, Tchesnokov EP, Woolner E, Perry JK, Feng JY, Porter DP, et al. Remdesivir is a direct-acting antiviral that inhibits RNA-dependent RNA polymerase from severe acute respiratory syndrome coronavirus 2 with high potency. Journal of Biological Chemistry 2020;jbc. RA120.013679.

11. Turner AJ, Hiscox JA, Hooper NM. ACE2: from vasopeptidase to SARS virus receptor. Trends in Pharmacological Sciences 2004;25(6):291-4.

12. Sriram K, Insel PA. Risks of ACE inhibitor and ARB usage in COVID-19: evaluating the evidence. Clinical Pharmacology \& Therapeutics 2020.

13. Rico-Mesa JS, White A, Anderson AS. Outcomes in patients with COVID-19 infection taking ACEI/ARB. Current Cardiology Reports 2020;22:1-4.

14. Danser AJ, Epstein M, Batlle D. Renin-angiotensin system blockers and the COVID-19 pandemic: at present there is no evidence to abandon renin-angiotensin system blockers. Hypertension. 2020; HYPERTENSIONAHA. 120.15082

15. Rodriguez-Morales Al, Cardona-Ospina JA, GutierrezOcampo E, Villamizar-Pena R, Holguin-Rivera Y, EscaleraAntezana JP, et al. Clinical, laboratory and imaging features of COVID-19: A systematic review and meta-analysis. Travel Med Infect Dis 2020;101623.

16. Zhang $C, W u Z, L i$ W, Zhao H, Wang G-Q. The cytokine release syndrome (CRS) of severe COVID-19 and Interleukin-6 receptor (IL-6R) antagonist Tocilizumab may be the key to reduce the mortality. Int I Antimicrob Agents 2020:105954.

17. Zhang S, Li L, Shen A, Chen Y, Qi Z. Rational Use of Tocilizumab in the Treatment of Novel Coronavirus Pneumonia. Clinical Drug Investigation 2020:1-8.

18. Zhang R, Wang X, Ni L, Di X, Ma B, Niu S, et al. COVID-19: Melatonin as a potential adjuvant treatment. Life Sci 2020;250:117583.
19. Bachanova V, Bishop MR, Dahi P, Dholaria B, Grupp SA, Hayes-Lattin B, et al. CAR $T$ Cell Therapy During the COVID-19 Pandemic. Biology of Blood and Marrow Transplantation 2020.

20. Aminjafari A, Ghasemi S. The possible of immunotherapy for COVID-19: A systematic review. International Immunopharmacology 2020:106455.

21. Chiappelli F, Khakshooy A, Greenberg G. COVID-19 immunopathology and immunotherapy. Bioinformation 2020;16(3):219.

22. Solaimanzadeh I. Acetazolamide, Nifedipine and phosphodiesterase inhibitors: rationale for their utilization as adjunctive countermeasures in the treatment of coronavirus disease 2019 (COVID-19). Cureus 2020;12(3):e7343.

23. Aghagoli G, Gallo Marin B, Soliman LB, Sellke FW. Cardiac involvement in COVID-19 patients: Risk factors, predictors, and complications: A review. Journal of Cardiac Surgery 2020.

24. Zheng YY, Ma YT, Zhang IY, Xie X. COVID-19 and the cardiovascular system. Nature Reviews Cardiology 2020;17(5):259-60.

25. Long B, Brady WJ, Koyfman A, Gottlieb M. Cardiovascular complications in COVID-19. Am J Emerg Med 2020.

26. Liu K, Fang YY, Deng Y, Liu W, Wang MF, Ma JP, et al. Clinical characteristics of novel coronavirus cases in tertiary hospitals in Hubei Province. Chinese Medical Journal 2020.

27. Liu Y, Yang $Y$, Zhang C, Huang F, Wang F, Yuan J, et al. Clinical and biochemical indexes from 2019-nCoV infected patients linked to viral loads and lung injury. Science China Life Sciences 2020;63(3):364-74.

28. Welt FG, Shah PB, Aronow HD, Bortnick AE, Henry TD, Sherwood MW, et al. Catheterization laboratory considerations during the coronavirus (COVID-19) pandemic: from ACC's Interventional Council and SCAI. I Am Coll Cardiol 2020.

29. Chen $T, W u D$, Chen $H$, Yan $W$, Yang $D$, Chen $G$, et al. Clinical characteristics of 113 deceased patients with coronavirus disease 2019: retrospective study. BMJ $2020 ; 368$.

30. Kwong JC, Schwartz KL, Campitelli MA, Chung $H$, Crowcroft NS, Karnauchow $T$, et al. Acute myocardial infarction after laboratory-confirmed influenza infection. N Engl J Med 2018;378(4):345-53.

31. Driggin E, Madhavan MV, Bikdeli B, Chuich T, Laracy J, Bondi-Zoccai G, et al. Cardiovascular considerations for patients, health care workers, and health systems during the coronavirus disease 2019 (COVID-19) pandemic. I Am Coll Cardiol 2020.

32. Danzi GB, Loffi M, Galeazzi G, Gherbesi E. Acute pulmonary embolism and COVID-19 pneumonia: a random association? Eur Heart / 2020. 
33. Xie Y, Wang X, Yang P, Zhang S. COVID-19 complicated by acute pulmonary embolism. Radiology: Cardiothoracic Imaging 2020;2(2):e200067.

34. Zhou F, Yu T, Du R, Fan G, Liu Y, Liu Z, et al. Clinical course and risk factors for mortality of adult inpatients with COVID-19 in Wuhan, China: a retrospective cohort study. The Lancet 2020.

35. Tang N, Bai H, Chen X, Gong J, Li D, Sun Z. Anticoagulant treatment is associated with decreased mortality in severe coronavirus disease 2019 patients with coagulopathy. Journal of Thrombosis and Haemostasis 2020.

36. Cheng $Y$, Luo R, Wang $K$, Zhang $M$, Wang Z, Dong $L$, et al. Kidney disease is associated with in-hospital death of patients with COVID-19. Kidney Int. 2020;97(5):829-38.

37. Pei G, Zhang Z, Peng J, Liu L, Zhang C, Yu C, et al. Renal Involvement and Early Prognosis in Patients with COVID19 Pneumonia. Journal of the American Society of Nephrology 2020.

38. Peleg Y, Kudose S, D'Agati V, Siddall E, Ahmad S, Kisselev $S$, et al. Acute Kidney Injury Due to Collapsing Glomerulopathy Following COVID-19 Infection. Kidney Int Rep 2020.

39. Moeinzadeh F, Dezfouli M, Naimi A, Shahidi S, Moradi H. Newly Diagnosed Glomerulonephritis During COVID-19 Infection Undergoing Immunosuppression Therapy, a Case Report. Iran J Kidney Dis 2020;14(3):239-42.

40. Tian Y, Rong L, Nian W, He Y. Review article: gastrointestinal features in COVID-19 and the possibility of faecal transmission. Aliment Pharmacol Ther 2020;51(9):84351.

41. Guan WJ, Ni ZY, Hu Y, Liang WH, Ou CQ, He JX, et al. Clinical characteristics of coronavirus disease 2019 in China. N Engl J Med 2020.

42. Chen N, Zhou M, Dong X, Qu J, Gong F, Han Y, et al. Epidemiological and clinical characteristics of 99 cases of 2019 novel coronavirus pneumonia in Wuhan, China: a descriptive study. The Lancet 2020;395(10223):507-13.

43. $X u X W, W u X X$, Jiang $X G, X u K J$, Ying $L J$, Ma $C L$, et al. Clinical findings in a group of patients infected with the 2019 novel coronavirus (SARS-Cov-2) outside of Wuhan, China: retrospective case series. BMJ 2020;368.

44. Fang D, Ma J, Guan J, Wang M, Song Y, Tian D. Manifestations of digestive system in hospitalized patients with novel coronavirus pneumonia in Wuhan, China: a single-center, descriptive study. Chin I Dig 2020;40(2020-02-23).

45. Zhang C, Shi L, Wang FS. Liver injury in COVID-19: management and challenges. The Lancet Gastroenterology \& Hepatology 2020.

46. Uhlen M, Fagerberg L, Hallström BM, Lindskog C, Oksvold P, Mardinoglu A, et al. Tissue-based map of the human proteome. Science 2015;347(6220):1260419.
47. Li J, Fan JG. Characteristics and mechanism of liver injury in 2019 coronavirus disease. Journal of Clinical and Translational Hepatology 2020;8(1):13.

48. Chen H DQ. Potential natural compounds for preventing 2019-nCoV infection. 2020(Preprint).

49. Feng $G$, Zheng $K I$, Yan $Q Q$, Rios RS, Targher $G$, Byrne $C D$, et al. COVID-19 and Liver Dysfunction: Current Insights and Emergent Therapeutic Strategies. I Clin Transl Hepatol 2020;8(1):18-24.

50. Recalcati S. Cutaneous manifestations in COVID-19: a first perspective. J Eur Acad Dermatol Venereol 2020.

51. Bouaziz $J D$, Duong $T$, Jachiet $M$, Velter $C$, Lestang $P$, Cassius $C$, et al. Vascular skin symptoms in COVID-19: a french observational study. I Eur Acad Dermatol Venereol 2020

52. Mahé A, Birckel E, Krieger S, Merklen C, Bottlaender L. A distinctive skin rash associated with Coronavirus Disease 2019 ? J Eur Acad Dermatol Venereol 2020.

53. Fernandez-Nieto D, Ortega-Quijano D, Segurado-Miravalles G, Pindado-Ortega C, Prieto-Barrios M, Jimenez-Cauhe J. Comment on: Cutaneous manifestations in COVID-19: a first perspective. Safety concerns of clinical images and skin biopsies. J Eur Acad Dermatol Venereol 2020.

54. Estébanez A, Pérez-Santiago L, Silva E, Guillen-Climent S, García-Vázquez A, Ramón MD. Cutaneous manifestations in COVID-19: a new contribution. I Eur Acad Dermatol Venereol 2020.

55. Guan WJ, Ni ZY, Hu Y, Liang WH, Ou CQ, He JX, et al. Clinical Characteristics of Coronavirus Disease 2019 in China. N Engl I Med 2020;382(18):1708-20.

56. Tammaro A, Adebanjo GAR, Parisella FR, Pezzuto A, Rello J. Cutaneous manifestations in COVID-19: the experiences of Barcelona and Rome. I Eur Acad Dermatol Venereol 2020 .

57. Arora G, Kassir M, Jafferany M, Galadari H, Lotti T, Satolli $F$, et al. The COVID-19 outbreak and rheumatologic skin diseases. Dermatol Ther 2020:e13357.

58. Tian $S, H u W$, Niu L, Liu H, Xu H, Xiao SY. Pulmonary pathology of early-phase 2019 novel coronavirus (COVID19) pneumonia in two patients with lung cancer. I Thorac Oncol 2020;15(5):700-4.

59. Yao XH, Li TY, He ZC, Ping YF, Liu HW, Yu SC, et al. A pathological report of three COVID-19 cases by minimally invasive autopsies. Zhonghua Bing $\mathrm{Li}$ Xue Za Zhi 2020;49(0):E009.

60. Xu Z, Shi L, Wang Y, Zhang J, Huang L, Zhang C, et al. Pathological findings of COVID-19 associated with acute respiratory distress syndrome. The Lancet Respiratory Medicine 2020;8(4):420-2.

61. Barton LM, Duval EJ, Stroberg E, Ghosh S, Mukhopadhyay S. COVID-19 autopsies, Oklahoma, USA. Am I Clin Pathol 2020 
62. Tian S, Xiong Y, Liu H, Niu L, Guo J, Liao $M$, et al. Pathological study of the 2019 novel coronavirus disease (COVID-19) through postmortem core biopsies. Mod Pathol 2020

63. Luo W YH, Gou J, Li X, Sun Y, Li J, Liu L. Clinical pathology of critical patient with novel coronavirus pneumonia (COVID-19). 2020(Preprint).

64. Karami P, Naghavi M, Feyzi A, Aghamohammadi M, Novin MS, Mobaien A, et al. Mortality of a pregnant patient diagnosed with COVID-19: A case report with clinical, radiological, and histopathological findings. Travel Med Infect Dis 2020:101665.

65. Liu Q, Wang RS, Qu GQ, Wang YY, Liu P, Zhu YZ, et al. Gross examination report of a COVID-19 death autopsy. Fa Yi Xue Za Zhi 2020;36(1):21-3.

66. Fox SE, Akmatbekov A, Harbert IL, Li G, Brown JQ, Vander Heide RS. Pulmonary and cardiac pathology in Covid-19: the first autopsy series from New Orleans. medRxiv 2020.

67. Konopka KE, Wilson A, Myers JL. Postmortem Lung Findings in an Asthmatic with Coronavirus Disease 2019 (COVID-19). Chest 2020.

68. Bradley BT, Maioli H, Johnston R, Chaudhry I, Fink SL, Xu $H$, et al. Histopathology and Ultrastructural Findings of Fatal COVID-19 Infections. medRxiv 2020.

69. Liu $Q$, Wang R, Qu G, Wang Y, Liu P, Zhu Y, et al. Gross examination report of a COVID-19 death autopsy. Fa Yi Xue Za Zhi 2020;36(1):21.
70. Su H, Yang M, Wan C, Yi LX, Tang F, Zhu HY, et al. Renal histopathological analysis of 26 postmortem findings of patients with COVID-19 in China. Kidney Int 2020.

71. Pei G, Zhang Z, Peng J, Liu L, Zhang C, Yu C, et al. Renal involvement and early prognosis in patients with COVID19 pneumonia. J Am Soc Nephrol 2020.

72. Xu X, Chang XN, Pan $H X$, Su $H$, Huang B, Yang $M$, et al. [Pathological changes of the spleen in ten patients with new coronavirus infection by minimally invasive autopsies]. Zhonghua Bing Li Xue Za Zhi 2020;49(0):E014.

73. Zengarini C, Orioni G, Cascavilla A, Horna Solera C, Fulgaro C, Misciali C, et al. Histological pattern in Covid19 induced viral rash. J Eur Acad Dermatol Venereol 2020.

74. Marzano AV, Genovese G, Fabbrocini G, Pigatto P, Monfrecola G, Piraccini BM, et al. Varicella-like exanthem as a specific COVID-19-associated skin manifestation: multicenter case series of 22 patients. I Am Acad Dermatol 2020.

75. Ahouach B, Harant S, Ullmer A, Martres P, Bégon E, Blum $L$, et al. Cutaneous lesions in a patient with COVID-19: are they related? Br I Dermatol 2020.

76. Magro C, Mulvey JJ, Berlin D, Nuovo G, Salvatore S, Harp I, et al. Complement associated microvascular injury and thrombosis in the pathogenesis of severe COVID-19 infection: a report of five cases. Transl Res 2020. 